\title{
Evaluation of Groundwater Quality Using CCME Water Quality Index in the Rooppur Nuclear Power Plant Area, Ishwardi, Pabna, Bangladesh
}

\author{
Md. Galal Uddin ${ }^{1, *}$, Md. Moniruzzaman², Mala Khan ${ }^{1}$ \\ ${ }^{1}$ Designated Reference Institute for Chemical Measurements, Bangladesh Council of Scientific and Industrial Research, \\ Dhaka, Bangladesh \\ ${ }^{2}$ Department of Geography and Environment, Jagannath University, Dhaka, Bangladesh \\ *Corresponding author: jalaluddin_re1987@yahoo.com
}

\begin{abstract}
Water Quality Index (WQI) is one of the most powerful and effective tools for analyzing overall characteristics of water quality any reservoirs, its way to transfer information on water quality trends to policy makers and the general public is with Indices. Our objective was to evaluate ground water quality in the Rooppur Nuclear Power Plant (RNPP) area, Pabna, Bangladesh using a Canadian Council of Ministers of the Environment (CCME) WQI. WQI represent a clear scenario about the usability of the water for different purposes. Water quality indices are useful for concise information in order to achieve a national perspective. Attempts have been made to review the WQI criteria for the appropriateness of drinking water sources. Till now any methodology is not developed for evaluation of water quality index purposes in Bangladesh. At the very recent a few researcher try to use WQI method for giving WQ rating in Bangladesh. But, has no specific guideline for indexing water resources. This study to explore a potential WQ indexing method which applies easily and measure overall WQ for managing purposes. Besides, the present article also highlights and draws attention towards the development of a new and globally accepted "Water Quality Index" in a simplified format, which may be used at large and could represent the reliable picture of water quality. In the present paper, water quality index (WQI) was estimated for the groundwater of Rooppur Nuclear Power Plant area within the study period. The study also identifies the critical pollutants affecting the groundwater quality during the study period. The indices have been computed for the winter season at 17 locations, namely GW1, GW2, GW3 etc. It was found that the water quality ranged from poor to marginal category at all locations. Alkalinity, Conductivity, BOD, DO, Iron, Arsenic, Lead, Nitrite and fecal coliforms were found to be critical parameters.
\end{abstract}

Keywords: CCME WQI 1.0, RNPP, water quality index, groundwater, arsenic, fecal coliform

Cite This Article: Md. Galal Uddin, Md. Moniruzzaman, and Mala Khan, "Evaluation of Groundwater Quality Using CCME Water Quality Index in the Rooppur Nuclear Power Plant Area, Ishwardi, Pabna, Bangladesh.” American Journal of Environmental Protection, vol. 5, no. 2 (2017): 33-43. doi: 10.12691/env-5-2-2.

\section{Introduction}

A water quality index (WQI) is a tool to assess the status of water quality at convinced times and locations. It helps to gather whole scenarios of water quality parameters into useful information that is modest and easily comprehensible and thus can be used by the state agencies as well as the general public. At the present stretch, fresh water is more precious for drinking purposes. Groundwater reservoirs one of them and more reliable sources of fresh water. But, these sources polluted by the various natural and human activities. Changes in the Physico-chemical characteristics of water quality are influenced not only by anthropogenic factors [34], but also by the combined interactive various natural processes such as hydrological conditions, topography and lithology, climate [11], precipitation inputs [1], catchment area, tectonic and edaphic factors [11], erosion, weathering of crustal materials and bedrock geology [13], in combination with environmental influence. Human activities are more significant factors whose are influence Physico-chemical characteristics of water quality; gradually this trends increasing very rapidly in developing countries in the world. To safeguard freshwater resources, it is important to develop a comprehensive water quality monitoring program all over the world. A water quality monitoring program could be designed on the basis of the information on the existing water quality, standards, anthropological effects and the 'use' criteria [28]. Water quality is one of the most significant issues in water resources management and monitoring of environment. In wide-ranging terms, water quality can be classified into three broad categories, namely physical, chemical and biological and each category has a number of parameters [18].

However, when a large number of samples analyzed and parameters are monitored, it becomes too difficult to 
evaluate and present the water quality as a single unit [47]. A water quality index (WQI) is a single dimensionless number expressing the water quality in a simple form by aggregating the measurements of selected parameters [26, 49]. WQI can be estimated on the basis of various physicochemical parameters. In the developing countries, it is the major and perilous challenge has been to develop cost-effective pollution control strategies with analytical cost as a limiting factor due to restricted funds $[15,16]$. Therefore, for such situations only few critical parameters must be used to evaluate WQI [28]. In the present study, the Canadian Council of Ministers of the EnvironmentWater Quality Index 1.0 (CCME WQI) was used, which is a well-accepted and universally applicable computer model for evaluating the water quality index (Canadian Council of Ministers of the Environment [7,26,28,44,46]. It can combine a variety of different measurement units in a single metric and is effective as a communication tool. The index has the ability to convey relative differences in water quality between sites even when the same objectives and variables are used (Canadian Council of Ministers of the Environment [7].

This study focus to evaluate the WQI in ground water of RNPP areas. The study highlights the dynamic parameters of groundwater which are affecting the water quality at the various locations in the agricultural based region Rooppur Nuclear power Plant surrounding area of Bangladesh. The whole study is divided into three segments: (a) application of CCME WQI 1.0. to the groundwater to evaluate water quality index of twenty two (22) selected parameters on the groundwater; (b) establishing the correlation between the water quality index and the different parameters at locations; (c) to identify the most critical parameters affecting the water quality of the drinking water in the study region.

\section{Water Quality Index}

The WQI procedures introduce early 1960. The first systematic WQI attempt for Categorization of water quality started in the mid-twentieth century by Horton in 1965 [10]. Then in 1970 Brown et al. developed a general Water quality index [26]. In 1982 Steinhart et al. applied a novel environmental quality index to sum up technical information on the status and trends in Great Lakes ecosystem. Water Quality Guidelines Task Group of the Canadian Council of Ministers of the Environment introduced WQI in Canada, in the mid-1990s [8,29]. Some frequently used WQI in public domains are the US National Sanitation Foundation Water Quality Index, NSFWQI, Florida Stream Water Quality Index, FWQI, British Columbia Water Quality Index, BCWQI, Oregon Water Quality Index, OWQI and the Canadian Water Quality Index Canadian Council of Ministers of the Environment [26]. The original BCWQI was modified into the CCME WQI, which was certified by the Canadian Council of Ministers of the Environment [14]. At first WQI was developed by Bhargava in the India subcontinent, wherein the water quality is expressed as a number (ranging from 0 for highly/extremely polluted to 100 for absolutely unpolluted water) representing the integrated effect of the parameters amplifying the pollution load [4]. In the developing countries, to develop cost effective pollution control strategies with analytical cost as a limiting factor due to restricted funds it is the great challenge. Therefore, Ongley in 1998 suggested, for such situations only few critical parameters must be used to evaluate WQI $[15,16]$. Many researchers has applied water quality index for representing the quality status post monitoring and analysis [17,50]. Primarily, WQI was developed by Horton (1965) in United States by selecting 10 most commonly used water quality variables like dissolved oxygen (DO), $\mathrm{pH}$, coliforms, specific conductance, alkalinity and chloride etc. and has been widely applied and accepted in European, African and Asian countries. The assigned weight reflected significance of a parameter for a particular use and has considerable impact on the index. Furthermore, a new WQI similar to Horton's index has also been developed by the group of Brown in 1970 [12]. Which was based on weights to individual parameter [18]. WQI is a mathematical tool which has the ability to provide a single number for the large quantities of water quality data in a comprehensive manner. Therefore, it is a simple tool for decision makers on the quality and possible uses of a given water body [17,20,26].

Though, a huge number of water quality indices viz. Weight Arithmetic Water Quality Index (WAWQI), National Sanitation Foundation Water Quality Index (NSFWQI) in the USA, Canadian Council of Ministers of the Environment Water Quality Index (CCMEWQI), Oregon Water Quality Index (OWQI), SRDD index, Oregon Index, Dinius' index [26], House's Index [26], Smith's index [45] and Almeida's Index [26] etc. have been formulated by several national and international state organizations and authorities. These WQI have been applied for evaluation of water quality in a particular area [18]. In general, till now any WQ indexing method isn't found which are used world-wide. But it seems to a few WQI method more widely used various organization and state agencies. The index developers might consider all the four steps in developing a WQI or they could consider some of the steps. Furthermore, there is no method by which $100 \%$ objectivity or accuracy can be achieved in the development of a WQI, specifically for the selection of parameters, generation of sub-index values, generation of parameter weights and the choice of index aggregation method. Thus, problems like inflexibility, hiding and vagueness will always be a challenge in the development of a WQI. Overall WQI method is a very complex processes because of expert opinion, judgment, mathematical and statistical combination is basic indices for formulation a WQI method [26].

Moreover, to identify a WQI method for applying in this study, method was chosen on the basis of more widely used in global scale at different state agencies and more acceptable which is extract overall scenario of WQ. Several studies in the literature have applied the CCME WQI index for various purposes. In Canada, it was used to evaluate the water quality status of several river basins $[12,44]$ to evaluate drinking water quality $[26,44]$ and to assess water quality in metal mines [26]. In addition to the abovementioned applications of CCME WQI in Canada, this index also has been adopted in several other countries. Besides, it was employed in Turkey [26], India [28], Spain [42], Chile [26], Albania [22] and Iran [43]. The CCME WQI was 
developed by the Canadian Council of Ministers of the Environment as a tool to assess and report water quality information to both management institutions and the public [7]. The CCME WQI index method adopt in this study.

\section{Materials and Methods}

Description of the study area

Water samples used in this work were collected from the RNPP area in Iswardhi and Lokkhikunda, Pabna district, Bangladesh. The study was conducted in Ishwardi (located in between $24^{\circ} 03^{\prime}$ and $24^{\circ} 15^{\prime}$ north latitudes and in between $89^{\circ} 00^{\prime}$ and $89^{\circ} 11^{\prime}$ east longitudes), the westernmost upazila of Pabna District in Rajshahi Division [41]. $120 \mathrm{~km}$ (75 miles) north of the capital, Dhaka. The area has a tropical monsoon climate with seasonality in rainfall distribution; the mean annual rainfall and temperature are $1872 \mathrm{~mm}$ and $36.8^{\circ} \mathrm{C}$, respectively. The upazila occupies an area of 250.89 sq. $\mathrm{km}$. It is bounded by Lalpur and Baraigram Upazila to the north, Kushtia Sadar and the Padma River to the south, Pabna Sadar and Atgharia Upazila to the east, Bheramara and Lalpur Upazila and Padma River to the west (BBS, 2012). The study area covered Lokkhikunda and Pakshy Union which area under the Iswardhi upazila. The Rooppur, Chor Rooppur, Notun Rooppur villages under the Pakshy Union (Figure 1). It is the site of the planned
Rooppur Nuclear Power Plant (RNPP).

Groundwater sampling and analysis

Sampling, preservation, and chemical analyzes were performed according to standard analytical methods for the examination of surface waters $[3,36]$ which are routinely applied in the water quality monitoring laboratories. Groundwater samples were collected from 17 water wells in January 2017. Sampled wells were homogeneously distributed over the study area as to represent the entire site. Well locations are shown in Figure 2. Each sampling location was recorded with a global positioning system (GPS). Pumps were operated for $10 \mathrm{~min}$. prior to sample collection [3]. Therefore, only data measured in the laboratory were used here. Unless otherwise specified in the methods, water samples were collected in $1 \mathrm{~L}$ polyethylene containers, stored in the dark at $4^{\circ} \mathrm{C}$, and analyzed within $24 \mathrm{~h}$. Water temperatures, $\mathrm{pH}$, electrical conductivity and dissolved oxygen were measured on the site while (by using standard electrochemical techniques; portable $\mathrm{pH}$, dissolved oxygen and conductivity meters, HANNA instruments) and in the laboratory. Water samples were analyzed for concentrations of seven (7) heavy metals like as lead $(\mathrm{Pb})$, chromium $(\mathrm{Cr})$, manganese $(\mathrm{Mn})$, iron $(\mathrm{Fe})$, copper $(\mathrm{Cu})$, cadmium (Cd), arsenic (As) using an Agilent 7500a inductively coupled plasma mass spectrometry (ICP-MS) at the Designated Reference Institute for Chemical Measurements, Dhaka, Bangladesh.

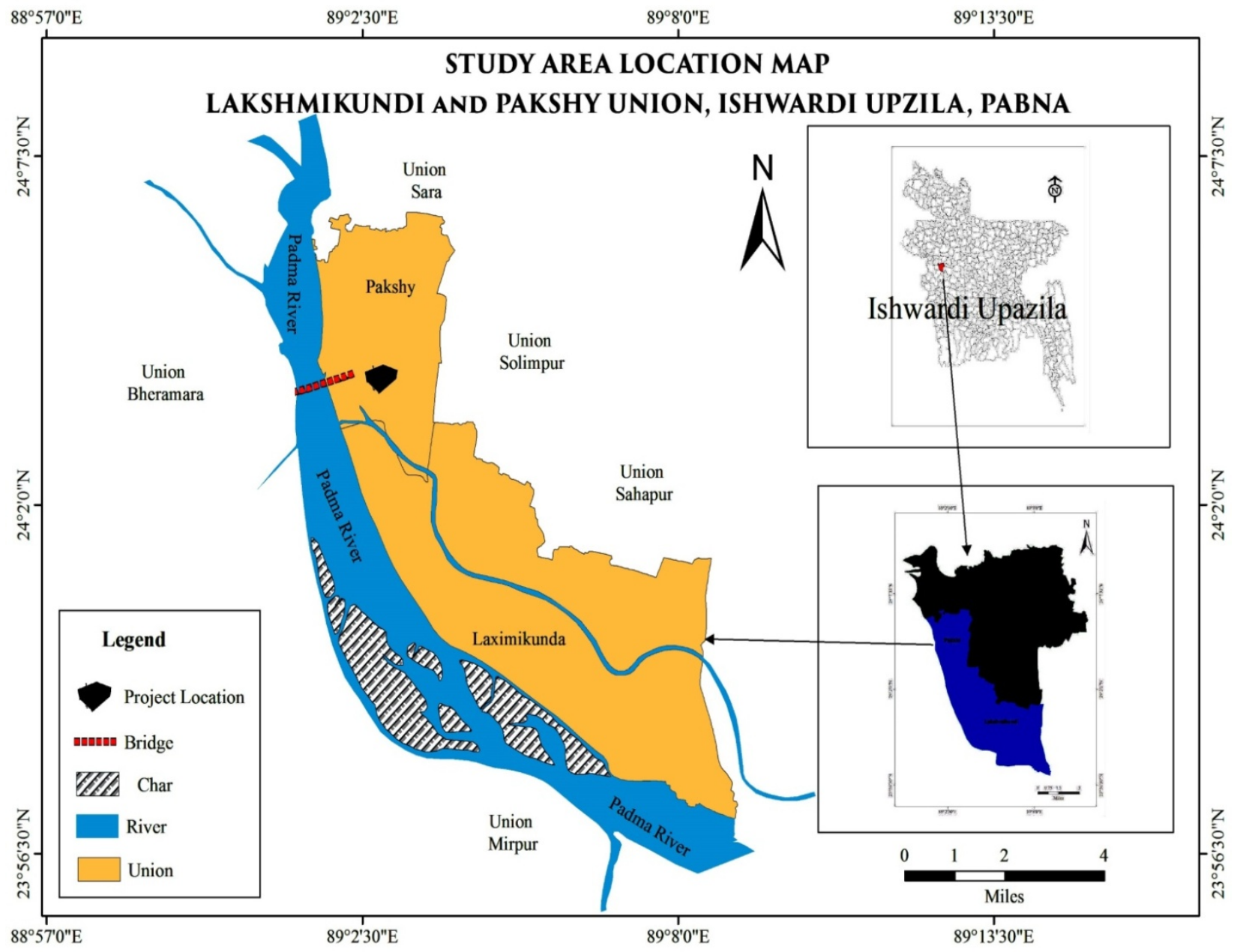

Figure 1. Location of the Study Area (Rooppur Nuclear Power Plant area), Ishwardi, Pabna, Bangladesh 


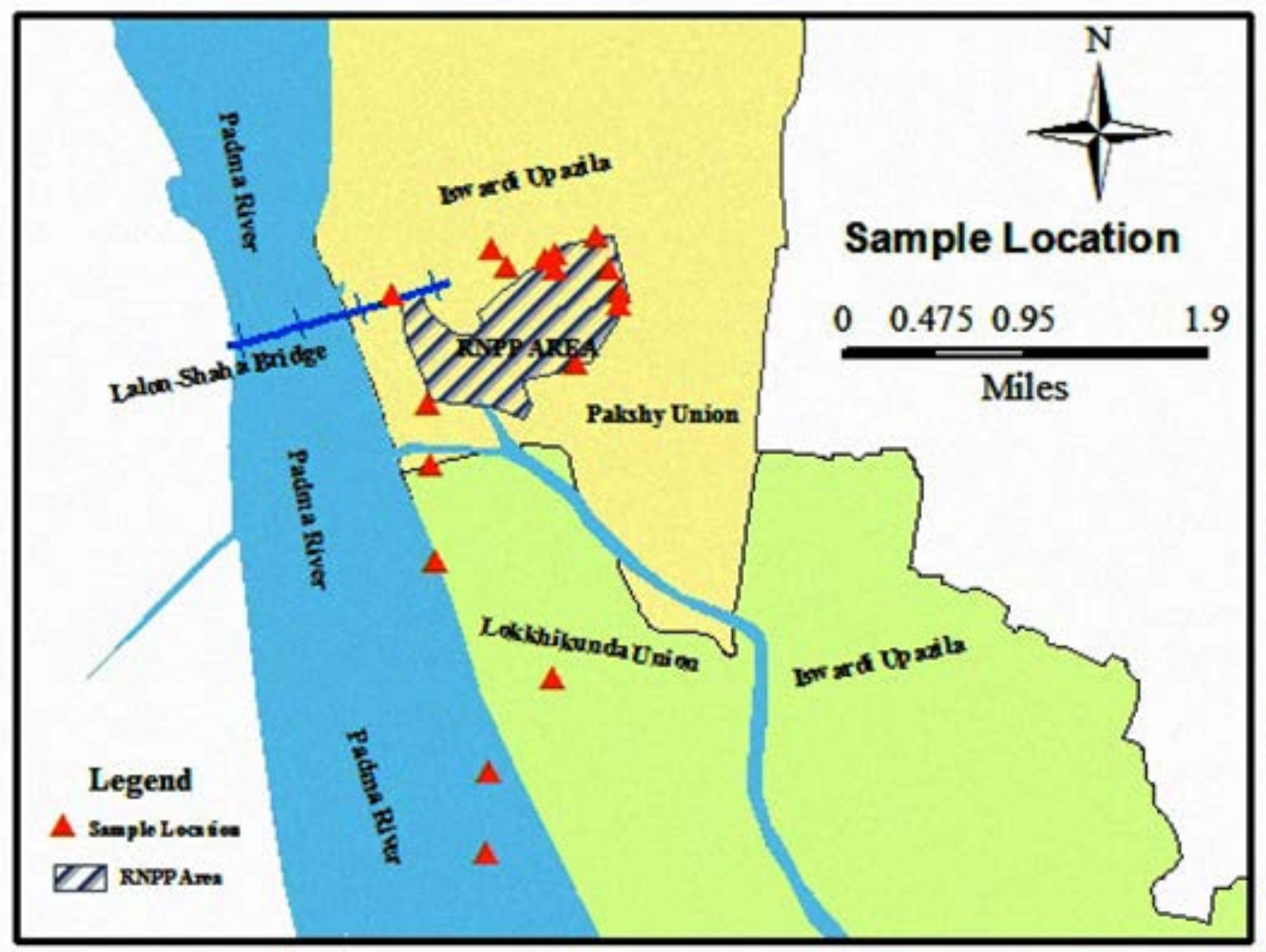

Figure 2. Sampling Location at RNPP area

\subsection{Conceptual framework of CCME Water Quality Index}

The CCME WQI comprises three factors and is well documented (Canadian Council of Ministers of the environment [6,7]. It is based on a formula developed by the British Columbia Ministry of Environment, Lands and Parks and modified by the Alberta Environment. The index is based on a combination of three factors:

1. Scope: the number of variables whose objectives are not met,

2. Frequency: the frequency with which the objectives are not met, and

3. Amplitude: the amount by which the objectives are not met

All these three factors are combined to produce a single value (between 0 and 100) that describes water quality. These numbers are divided into five descriptive categories to simplify presentation. It can be applied to different environmental settings since the specific variables, objectives and time period used in the index are not specified and, indeed, could vary from region to region, depending on local conditions and issues. Minimum of four variables must be sampled at least four times to be used in the calculation of index values. The calculation is done in the following steps:

After the body of water, the period of time, and the variables and objectives have been defined, each of the three factors that make up the index must be calculated. The calculation of F1 and F2 is relatively straightforward; F3 requires some additional steps. F1 (Scope) represents the percentage of variables that do not meet their objectives at least once during the time period under consideration ("failed variables"), relative to the total number of variables measured:

$$
F 1=\left[\frac{\text { Number of failed variables }}{\text { Total number of variable }}\right] \times 100
$$

F2 (Frequency) represents the percentage of individual tests that do not meet objectives ("failed tests"):

$$
\text { F2 }=\left[\frac{\text { Number of failed tests }}{\text { Total number of tests }}\right] \times 100
$$

F3 (Amplitude) represents the amount by which failed test values do not meet their objectives. F3 is calculated in three steps.

i) The number of times by which an individual concentration is greater than (or less than, when the objective is a minimum) the objective is termed an "excursion" and is expressed as follows. When the test value must not exceed the objective:

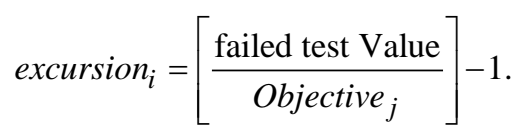

For the cases in which the test value must not fall below the objective:

$$
\text { excursion }_{i}=\left[\frac{\text { Objective }_{j}}{\text { Failed Test value }_{\mathrm{i}}}\right]-1 .
$$

ii) The collective amount by which individual tests are out of compliance is calculated by summing the 
excursions of individual tests from their objectives and dividing by the total number of tests (both those meeting objectives and those not meeting objectives). This variable, referred to as the normalized sum of excursions, or nse, is calculated as:

$$
\text { nse }=\left[\frac{\sum_{i=1}^{n} \text { excursion }_{j}}{\text { TotalNumberofTest }}\right]-1 .
$$

iii) F3 is then calculated by an asymptotic function that scales the normalized sum of the excursions from objectives (nse) to yield a range between 0 and 100 .

$$
\mathrm{F} 3=\left[\frac{\text { nse }}{0.01(\text { nse })+0.01}\right] .
$$

Once the factors have been obtained, the index itself can be calculated by summing the three factors as if they were vectors. The sum of the squares of each factor is therefore equal to the square of the index. This approach treats the index as a three-dimensional space defined by each factor along one axis. With this model, the index changes in direct proportion to changes in all three factors.

THE CCME WATER QUALITY INDEX (CCME WQI)

$$
\text { CCMEWQI }=100-\left(\frac{\sqrt{F 1^{2}+F 2^{2}+F 3^{2}}}{1.732}\right) .
$$

The divisor 1.732 normalizes the resultant values to a range between 0 and 100, where 0 represents the "worst" water quality and 100 represents the "best" water quality. Once the CCME WQI value has been determined, water quality is ranked by relating it to one of the following categories:

Excellent (CCME WQI Value 95-100)—water quality is protected with a virtual absence of threat or impairment; conditions are very close to natural or pristine levels

Good (CCME WQI Value 80-94) —water quality is protected with only a minor degree of threat or impairment; conditions rarely depart from natural or desirable levels

Fair (CCME WQI Value 65-79)—water quality is usually protected, but occasionally threatened or impaired; conditions sometimes depart from natural or desirable levels

Marginal (CCME WQI Value 45-64)_-water quality is frequently threatened or impaired; conditions often depart from natural or desirable levels

Poor (CCME WQI Value 0-44)—water quality is almost always threatened or impaired; conditions usually depart from natural or desirable levels (Canadian Council of Ministers of the Environment (CCME 2001)

The WQI software has been prepared in Visual Basic by CCME, which can be implemented in MS Excel for computational purpose. Instructions for the implementation are well described in the Calculator Version 1.0 (Canadian Council of Ministers of the Environment [6,7]. The output is available in the form of a table displaying the values of F1, F2, F3, WQI, number of samples, number of variables tested, total number of variables, total tests, failed tests, passed tests and tests below detection level. A frequency histogram of F1, F2 and F3 is also given [12].

Application of CCME WQI
The water quality index was calculated considering 22 physicochemical parameters using BDS standards. The The critical parameters was chosen to evaluate the WQI were Temperature, $\mathrm{pH}$, Dissolve Oxygen, Biological Oxygen Demand, Chemical Oxygen Demand, Conductivity, Alkalinity, Magnesium, Potassium, Sodium, Chloride, Nitrate, Nitrite, Sulphate, Manganese, Arsenic, Copper, Iron, Lead, Cadmium, Chromium and fecal coliforms (FC). The selected physicochemical parameters were very important for using groundwater as drinking purposes. The data of these variables are used in the calculation of CCME-WQI model using sets of Bangladesh standard (objectives) values of drinking water quality (Table 4).

\section{Results and Discussion}

The ground WQI for all the locations is presented in Figure 6. The WQI for study period are shown in Table 6. The histograms for three factors have been shown in Figure 3, Figure 4 and Figure 5 representing the scope, frequency and amplitude. The maximum number of variables whose objectives are not met lie in the range from 85 to 90 . The frequency with which the objectives are not met is highest between the ranges 65 and 70 and the amount by which the objectives are not met is highest between 95 and 100 .

It was observed (Table 6) that the range of CCME WQI for ground water at RNPP area at GW1, GW7, GW9, GW10, GW14, GW15 and GW16 sampling site falls under poor category and other sampling sites falls under marginal category during study period in January 2017. The amplitude calculated by the index helps in identifying the critical parameters after quantifying the amount by which failed test values do not meet the objectives. At all location Temperature, DO, BOD, COD, Conductivity, Alkalinity, Magnesium, Chloride, Nitrite, Iron, Lead and fecal coliforms were found to be critical and other parameters were well within the limits (Table 4). The water quality at this location reflects the impact of agricultural and industrial waste water interflow to groundwater.

\subsection{Discussion}

In this study, the primary focus was on twenty two (22) water quality parameters. It was observed that for locations seven location the water quality falls in the poor range of CCME WQI. It was also noted that $\mathrm{pH}$ was the only parameter meeting the water quality standards throughout the stretch. The presence of free ammonia is also an important parameter influencing the quality of the river and in high concentrations negatively impacts the river quality.

The data of physical, chemical, and bacteriological properties given in Table 4 and Table 5 indicate that the values of all Magnesium, Potassium, Sodium, Chloride, Nitrate, Nitrite, Sulphate, Manganese, Arsenic, Copper, Iron, Lead, Cadmium, Chromium parameters are below the maximum permissible limits indicated in the Bangladesh Standard [5,9,37] for drinking water (Table 4). A few parameters exceed maximum permissible limits of BDS 2000 guideline for drinking water quality. 
Temperature is very important for water to manage quality. It is responsible for all change of physicochemical parameters of water [21]. The temperature of the study area was investigated to be in the range of 22.30 to $28.00^{\circ} \mathrm{C}$ and the temperature values falls within the recommended range of temperature for drinking water quality (objective) in investigated period. The mean temperature was calculated $26.29 \pm 1.64^{\circ} \mathrm{C}$ during the study session. The $\mathrm{pH}$ measurement reflects a change in the quality of the source [3]. Very acidic or very alkaline water alkaline tastes [38]. Also, higher values of $\mathrm{pH}$ reduce germicidal potential of chlorine [23]. In this study, the $\mathrm{pH}$ value were ranged from 6.20 to 7.40 (Table 1). The average $\mathrm{pH}$ value was investigated $6.55 \pm 0.32$. They are within the objective range of 6.5 to 8.5 for drinking water quality (Table 4).The EC value is an index that represents the concentration of soluble salts in water $[3,5,23]$. The EC values for the investigated period recorded from 552.00 to $969.00 \mu \mathrm{s} / \mathrm{cm}$, where the mean EC are was recorded $793.53 \mu \mathrm{s} / \mathrm{cm}$ (Table 1). However, the observed EC values higher than the Bangladesh Standard for drinking water quality of $250 \mu \mathrm{s} / \mathrm{cm}$ (Table 4). The conductivity of groundwater was not met with objective value (Table 4). All sampling sites conductivity values falls out of the ranged BDS guideline for drinking water quality (Table 5).

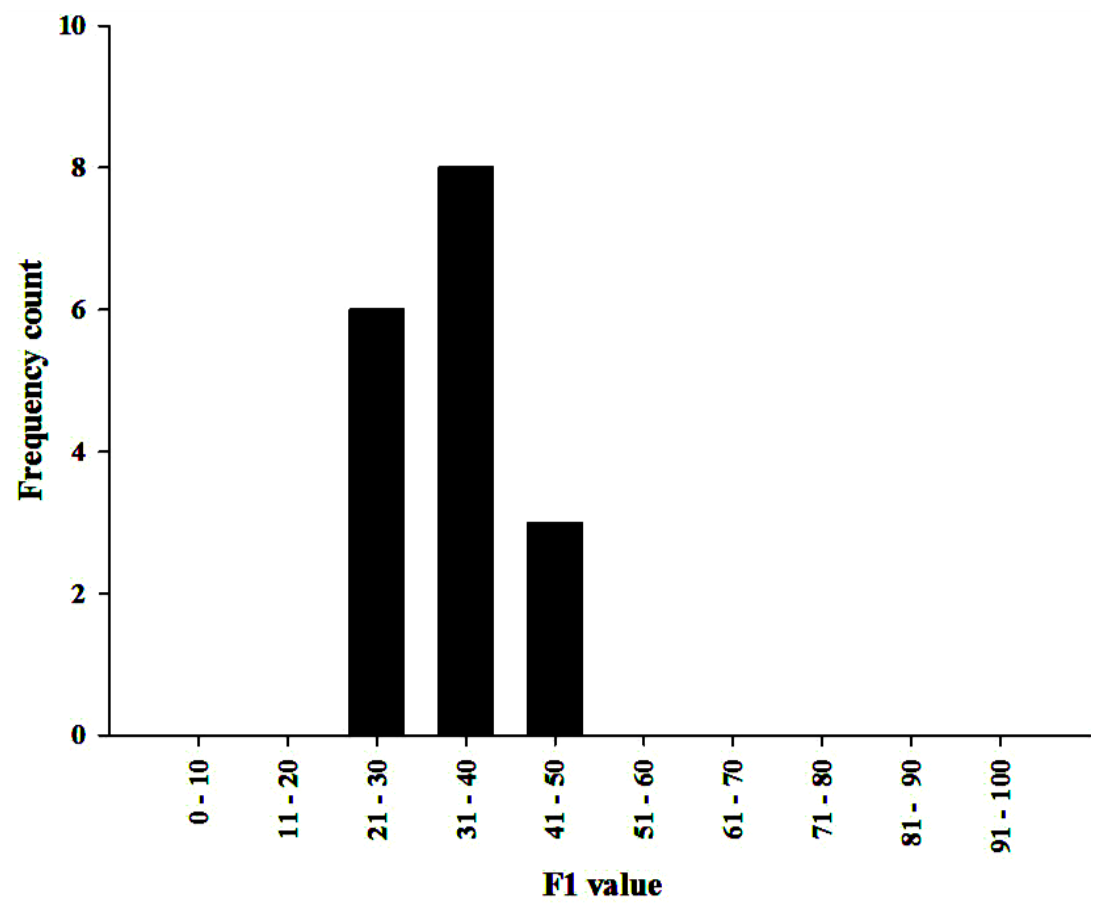

Figure 3. Histogram showing distribution of F1 parameter

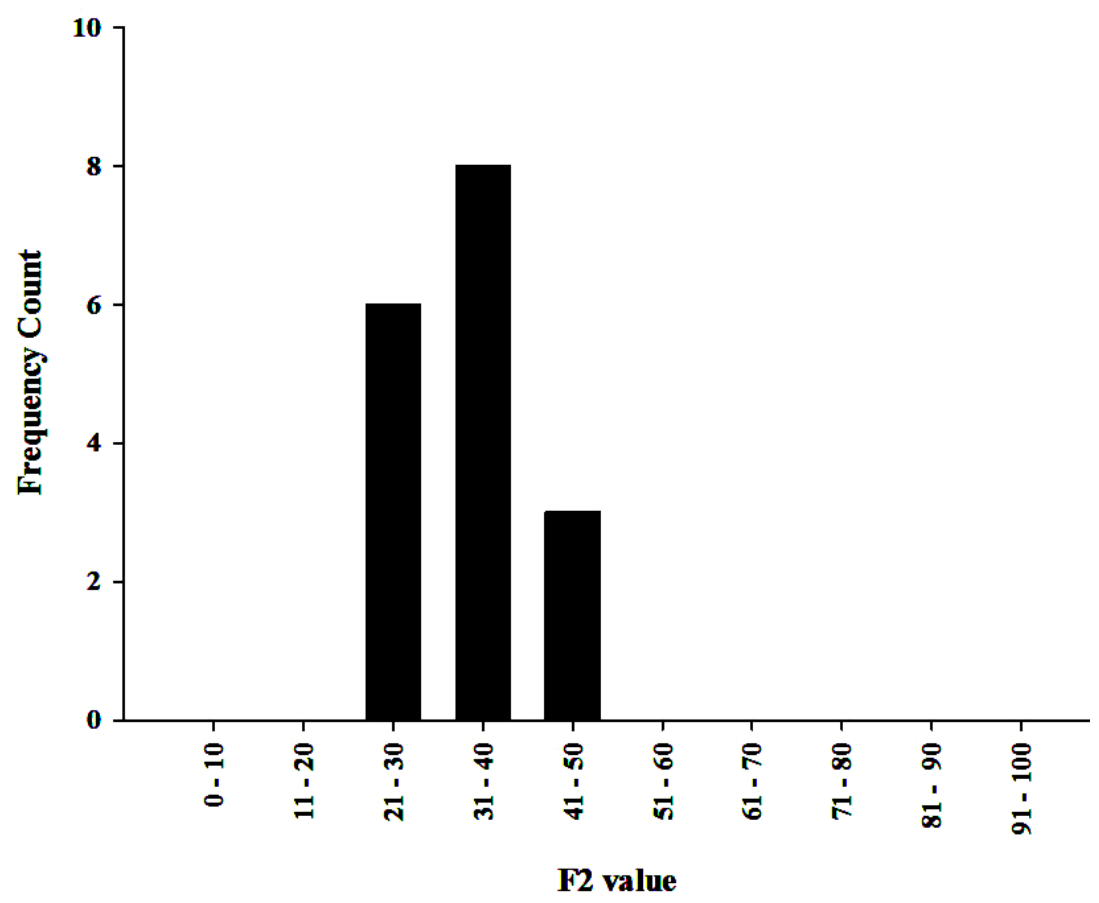

Figure 4. Histogram showing distribution of F2 parameter 
Table 1. Statistics summery of ground water quality parameters

\begin{tabular}{|c|c|c|c|c|c|c|c|}
\hline \multirow{2}{*}{ WQ Parameters } & \multicolumn{7}{|c|}{ Statistical Parameters } \\
\hline & Mean & SEM & Median & Mode & SD & Minimum & Maximum \\
\hline Temp. & 26.29 & .39815 & 26.6000 & 25.20 & 1.64 & 22.30 & 28.00 \\
\hline $\mathrm{pH}$ & 6.55 & 0.08 & 6.60 & 6.70 & 0.32 & 6.20 & 7.40 \\
\hline $\mathrm{DO}$ & 2.88 & 0.07 & 2.80 & 2.70 & 0.31 & 2.40 & 3.60 \\
\hline BOD & 10.35 & 4.14 & 0.00 & 0.00 & 17.06 & 0.00 & 58.00 \\
\hline COD & 793.5 & 24.83 & 817 & 552.00 & 102.4 & 552.00 & 969.0 \\
\hline F. Coli. & 24.74 & 14.413 & 3.00 & $<3$ & 59.42 & $<3$ & 210 \\
\hline Condu. & 793.5 & 24.83 & 817 & 552 & 102.4 & 552.00 & 969.0 \\
\hline Alkal. & 327.6 & 27.65 & 370 & 370 & 113.9 & 70.00 & 500.0 \\
\hline $\mathrm{Na}$ & 15.16 & 3.47 & 8.60 & 8.60 & 14.33 & 4.30 & 58.80 \\
\hline K & 3.13 & 0.16 & 3.20 & 3.20 & 0.689 & 1.20 & 4.20 \\
\hline $\mathrm{Mg}$ & 25.37 & 1.05 & 25.5000 & 28.50 & 4.34 & 16.40 & 33.90 \\
\hline $\mathrm{Cl}^{-}$ & 17.17 & 5.62 & 8.56 & $.32^{\mathrm{a}}$ & 23.18 & 0.32 & 70.80 \\
\hline $\mathrm{NO}_{3}^{-}$ & 31.69 & 31.01 & 0.53 & 0.00 & 127.9 & 0.00 & 527.8 \\
\hline $\mathrm{SO}_{4}{ }^{2-}$ & 4.794 & 1.62 & 1.100 & 0.0 & 6.69 & 0.0 & 20.2 \\
\hline $\mathrm{NO}_{2}^{-}$ & 3.33 & 1.56 & 0.00 & 0.00 & 6.45 & 0.00 & 24.18 \\
\hline $\mathrm{Mn}$ & 0.00101 & 0.00 & 0.00100 & 0.00048 & 0.0004 & 0.00048 & 0.00204 \\
\hline Iron & 0.21701 & 0.03 & 0.19730 & 0.07650 & 0.11660 & 0.07650 & 0.49670 \\
\hline $\mathrm{Cu}$ & 0.00278 & 0.0006 & 0.00189 & 0.00150 & 0.00249 & 0.00118 & 0.00996 \\
\hline As & 0.04989 & 0.0298 & 0.00331 & 0.00090 & 0.123 & 0.00090 & 0.49835 \\
\hline $\mathrm{Cr}$ & 0.00241 & 0.0002 & 0.00217 & 0.00129 & 0.00091 & 0.00129 & 0.00402 \\
\hline $\mathrm{Cd}$ & 0.00003 & 0.00001 & 0.00002 & 0.00002 & 0.00004 & 0.00000 & 0.00019 \\
\hline $\mathrm{Pb}$ & 0.007 & 0.00014 & 0.00056 & 0.00062 & 0.00056 & 0.00018 & 0.00244 \\
\hline
\end{tabular}

*Except $\mathrm{pH}$, Temperature, Conductivity and Fecal. Coliform other parameters are in mg/L.

Table 2. Correlation between WQI and water quality parameters

\begin{tabular}{|c|c|c|c|c|c|c|c|c|c|c|c|c|c|}
\hline WQ Parameter & Tem. & $\mathrm{pH}$ & DO & BOD & COD & F. Coli. & Cond. & Alkali. & $\mathrm{Cl}^{-}$ & $\mathrm{NO}_{3}^{2-}$ & $\mathrm{NO}_{2}{ }^{2-}$ & Mn & WQI \\
\hline Tem. & 1 & & & & & & & & & & & & \\
\hline $\mathrm{pH}$ & -0.191 & 1 & & & & & & & & & & & \\
\hline DO & $-.693^{* *}$ & -0.26 & 1 & & & & & & & & & & \\
\hline BOD & -0.107 & -0.004 & 0.051 & 1 & & & & & & & & & \\
\hline COD & -0.204 & 0.149 & 0.241 & 0.034 & 1 & & & & & & & & \\
\hline F. Coli. & -0.466 & 0.002 & -0.007 & 0.241 & 0.072 & 1 & & & & & & & \\
\hline Cond. & -0.204 & 0.149 & 0.241 & 0.034 & $1.000^{* *}$ & 0.072 & 1 & & & & & & \\
\hline Alkali. & 0.429 & -0.388 & -0.255 & -0.047 & 0.081 & -0.253 & 0.081 & 1 & & & & & \\
\hline Cl- & -0.395 & -0.321 & $.654^{* *}$ & -0.182 & 0.478 & 0.197 & 0.478 & -0.166 & 1 & & & & \\
\hline $\mathrm{NO}_{3}{ }^{2-}$ & 0.045 & -0.284 & 0.19 & -0.155 & 0.357 & -0.091 & 0.357 & 0.389 & $.597^{*}$ & 1 & & & \\
\hline $\mathrm{NO}_{2}{ }^{2-}$ & 0.047 & -0.133 & 0.084 & 0.198 & -0.276 & -0.201 & -0.276 & 0.079 & -0.358 & -0.133 & 1 & & \\
\hline $\mathrm{Mn}$ & 0.203 & 0.149 & -0.185 & -0.267 & 0.168 & -0.169 & 0.168 & -0.158 & 0.026 & 0.277 & -0.032 & 1 & \\
\hline WQI & 0.006 & 0.099 & -0.135 & -0.174 & -0.041 & 0.185 & -0.041 & -0.034 & -0.054 & -0.434 & $-.551 *$ & -.598* & 1 \\
\hline${ }^{*}$ Correlation is $\mathrm{s}$ & ificant a & he $0.05 \mathrm{l}$ & el; ${ }^{* *} \mathrm{Co}$ & elation i & iønifican & the 0.01 & & & & & & & \\
\hline
\end{tabular}

Table 3. Correlation between WQI and water quality parameters

\begin{tabular}{|l|c|c|c|c|c|c|c|c|c|c|c|}
\hline WQ Parameters & $\mathrm{Fe}$ & $\mathrm{Na}^{+}$ & $\mathrm{SO}_{4}{ }^{2-}$ & $\mathrm{K}^{+}$ & $\mathrm{Pb}$ & $\mathrm{Cu}$ & $\mathrm{As}$ & $\mathrm{Cr}$ & $\mathrm{Cd}$ & $\mathrm{Mg}$ & $\mathrm{WQI}$ \\
\hline $\mathrm{Fe}$ & 1 & & & & & & & & & & \\
\hline $\mathrm{Na}^{+}$ & -0.38 & 1 & & & & & & & & & \\
\hline $\mathrm{SO}_{4}{ }^{2-}$ & -0.149 & 0.38 & 1 & & & & & & & & \\
\hline $\mathrm{K}^{+}$ & 0.015 & 0.026 & 0.241 & 1 & & & & & & & \\
\hline $\mathrm{Pb}$ & 0.361 & -0.158 & 0.03 & 0.091 & 1 & & & & & & \\
\hline $\mathrm{Cu}$ & -0.051 & -0.088 & -0.136 & 0.122 & 0.427 & 1 & & & & & \\
\hline $\mathrm{As}$ & $.585^{*}$ & -0.148 & -0.272 & -0.434 & 0.063 & -0.036 & 1 & & & & \\
\hline $\mathrm{Cr}$ & -0.04 & -0.259 & 0.272 & 0.213 & 0.269 & 0.464 & -0.263 & 1 & & & \\
\hline $\mathrm{Cd}$ & 0.238 & -0.116 & -0.119 & -0.225 & $.848^{* *}$ & $.495^{*}$ & 0.227 & 0.267 & 1 & & \\
\hline $\mathrm{Mg}$ & 0.328 & 0.088 & 0.26 & $.513^{*}$ & 0.384 & 0.299 & -0.216 & $.617^{* *}$ & 0.202 & 1 & \\
\hline WQI & $-.764^{* * *}$ & 0.226 & 0.318 & 0.251 & -0.334 & -0.047 & $-.605^{*}$ & 0.35 & -0.425 & -0.051 & 1 \\
\hline${ }^{*}$ Correlation is significant at the 0.05 level; ${ }^{* *}$ Correlation is significant at the 0.01 level & & & \\
\hline
\end{tabular}


Table 4. Physico-chemical parameters in ground water of RNPP area

\begin{tabular}{|c|c|c|c|c|c|c|c|c|c|c|c|c|}
\hline \multirow{2}{*}{ Sample ID } & \multicolumn{12}{|c|}{ Water Quality Parameters } \\
\hline & Temp & Condl & DO & pH & Alk & $\mathrm{Na}$ & Mg & $\mathbf{K}$ & Sulphate & Chloride & Nitrate & Nitrite \\
\hline GW1 & 25.2 & 834 & 2.8 & 7.4 & 70 & 10.22 & 28.29 & 2.77 & 3.31 & 16.48 & 0 & 0 \\
\hline GW2 & 22.3 & 833 & 3.2 & 6.7 & 170 & 16.74 & 28.6 & 2.85 & 17.3 & 41.87 & 2.88 & 0 \\
\hline GW3 & 26.2 & 882 & 2.7 & 7 & 430 & 8.47 & 33.91 & 4.18 & 4.77 & 13.1 & 0 & 0 \\
\hline GW4 & 23.3 & 755 & 3.3 & 6.6 & 370 & 13.72 & 25.13 & 3.79 & 3.35 & 16.48 & 1.823 & 0 \\
\hline GW5 & 27.1 & 782 & 2.4 & 6.3 & 370 & 7.87 & 24.7 & 3.22 & 6.62 & 11.87 & 0 & 0 \\
\hline GW6 & 25.2 & 969 & 3.6 & 6.2 & 190 & 58.78 & 30.2 & 3.79 & 20.2 & 70.74 & 0 & 0 \\
\hline GW7 & 26.6 & 936 & 3.1 & 6.2 & 500 & 12.18 & 28.49 & 4.13 & $<1$ & 70.8 & 527.805 & 0 \\
\hline GW8 & 27.3 & 552 & 2.8 & 6.2 & 240 & 4.34 & 16.42 & 3.23 & 11.78 & 29.26 & 0.94 & 0 \\
\hline GW9 & 25.2 & 666 & 3.2 & 6.3 & 330 & 5.33 & 22.62 & 2.62 & 0 & 4.25 & & 24.18 \\
\hline GW10 & 26.3 & 846 & 2.7 & 6.4 & 370 & 8.58 & 27.37 & 3.3 & 13 & 5.79 & 0 & 0 \\
\hline GW11 & 27.7 & 828 & 2.7 & 6.6 & 450 & 5.81 & 26.75 & 3.18 & 1.14 & 8.56 & 0.7125 & 0 \\
\hline GW12 & 28 & 740 & 2.6 & 6.7 & 250 & 4.57 & 21.43 & 2.97 & $<1$ & 0.37 & 1.155 & 0 \\
\hline GW13 & 27.6 & 787 & 2.6 & 6.7 & 420 & 35.81 & 22.46 & 2.97 & $<1$ & 0.49 & 0.4575 & 7.858 \\
\hline GW14 & 27.7 & 712 & 2.7 & 6.7 & 310 & 27.99 & 20.36 & 2.88 & $<1$ & 0.32 & 0.5325 & 7.681 \\
\hline GW15 & 27.9 & 861 & 2.7 & 6.4 & 380 & 5.55 & 28.54 & 2.66 & $<1$ & 0.55 & 0 & 10.186 \\
\hline GW16 & 27.5 & 690 & 2.9 & 6.3 & 430 & 23.24 & 20.5 & 1.21 & $<1$ & 0.59 & 0.7425 & 0 \\
\hline GW17 & 25.8 & 817 & 2.9 & 6.7 & 290 & 8.62 & 25.54 & 3.39 & $<1$ & 0.39 & 0.48 & 6.75 \\
\hline Objective & $20-30$ & 250 & 6 & $6.5-8.5$ & 100 & 200 & 30-35 & 12 & 400 & 150-600 & 10 & $<1$ \\
\hline
\end{tabular}

Table 5. Physico-chemical parameters in ground water of RNPP area.

\begin{tabular}{|l|c|c|c|c|c|c|c|c|c|c|}
\hline \multirow{2}{*}{ Sample ID } & \multicolumn{10}{|c|}{ Water Quality Parameters } \\
\cline { 2 - 12 } & As & Cd & Cr & Cu & Fe & Mn & Pb & BOD & COD & F. Coliform \\
\hline GW1 & $\mathbf{0 . 0 8 4 2 7}$ & 0.00019 & 0.00336 & $\mathbf{0 . 0 0 7 7}$ & 0.2577 & 0.002 & 0.00244 & $\mathbf{1 4 . 1 4}$ & $\mathbf{1 9 2}$ & $<3$ \\
\hline GW2 & 0.00331 & 0.00002 & 0.00402 & $\mathbf{0 . 0 0 2 2}$ & 0.1973 & 0.0005 & 0.00046 & $\mathbf{3 7}$ & 0 & $<3$ \\
\hline GW3 & 0.00316 & 0.00004 & 0.004 & $\mathbf{0 . 0 0 5 2}$ & $\mathbf{0 . 3 1 5 7}$ & 0.0006 & 0.00145 & $\mathbf{1 3 . 6 3}$ & $\mathbf{6 4}$ & $<3$ \\
\hline GW4 & 0.00096 & 0 & 0.00276 & $\mathbf{0 . 0 0 1 3}$ & 0.108 & 0.0007 & 0.00018 & $\mathbf{1 6}$ & $\mathbf{9 6}$ & $<3$ \\
\hline GW5 & 0.0025 & 0.00002 & 0.00282 & $\mathbf{0 . 0 0 1 2}$ & 0.138 & 0.0013 & 0.00019 & $\mathbf{1 2 . 1 2}$ & $\mathbf{1 1 2}$ & $<3$ \\
\hline GW6 & 0.0009 & 0.00001 & 0.00214 & $\mathbf{0 . 0 0 2 6}$ & 0.1307 & 0.001 & 0.00047 & $\mathbf{1 8 . 1 8}$ & $\mathbf{1 6}$ & $<3$ \\
\hline GW7 & 0.02497 & 0.00002 & 0.00135 & $\mathbf{0 . 0 0 2 2}$ & $\mathbf{0 . 3 2 8}$ & 0.0014 & 0.00061 & $\mathbf{1 3 2}$ & $\mathbf{4 8}$ & $<3$ \\
\hline GW8 & 0.00247 & 0.00001 & 0.00164 & $\mathbf{0 . 0 0 1 5}$ & 0.1577 & 0.0006 & 0.00056 & $\mathbf{1 4 . 1 4}$ & $\mathbf{4 8}$ & $<3$ \\
\hline GW9 & $\mathbf{0 . 4 9 8 3 5}$ & 0.00004 & 0.00152 & $\mathbf{0 . 0 0 1 9}$ & $\mathbf{0 . 4 9 6 7}$ & 0.0011 & 0.00067 & $\mathbf{1 1 7}$ & $\mathbf{1 2 8}$ & $<3$ \\
\hline GW10 & 0.00324 & 0.00002 & 0.00219 & $\mathbf{0 . 0 0 1 4}$ & $\mathbf{0 . 3 0 8}$ & 0.0014 & 0.00116 & $\mathbf{2 2}$ & $\mathbf{6 4}$ & $<3$ \\
\hline GW11 & 0.02352 & 0.00002 & 0.00327 & $\mathbf{0 . 0 0 1 6}$ & 0.2463 & 0.0008 & 0.00031 & $\mathbf{1 6 . 8 1}$ & $\mathbf{8 0}$ & $<3$ \\
\hline GW12 & 0.00158 & 0.00001 & 0.00202 & $\mathbf{0 . 0 0 1 5}$ & 0.085 & 0.0011 & 0.00062 & $\mathbf{1 6 . 1 9}$ & $\mathbf{3 2}$ & $<3$ \\
\hline GW13 & 0.00884 & 0.00002 & 0.00133 & $\mathbf{0 . 0 0 1 4}$ & 0.0765 & 0.0009 & 0.00062 & $\mathbf{1 6 . 1 9}$ & $\mathbf{1 6}$ & $<3$ \\
\hline GW14 & 0.01037 & 0.00002 & 0.00129 & $\mathbf{0 . 0 0 2 1}$ & 0.2155 & 0.001 & 0.00049 & $\mathbf{2 9}$ & $\mathbf{4 8}$ & $<3$ \\
\hline GW15 & 0.01221 & 0.00002 & 0.00217 & $\mathbf{0 . 0 0 1 2}$ & $\mathbf{0 . 3 7 1}$ & 0.001 & 0.00064 & $\mathbf{5 8}$ & $\mathbf{6 4}$ & $<3$ \\
\hline GW16 & $\mathbf{0 . 1 6 5 4 5}$ & 0.00004 & 0.00188 & $\mathbf{0 . 0 0 2 4}$ & 0.143 & 0.0012 & 0.00026 & $\mathbf{1 8 . 0 6}$ & $\mathbf{6 4}$ & $<3$ \\
\hline GW17 & 0.00209 & 0.00001 & 0.00314 & $\mathbf{0 . 0 1}$ & 0.114 & 0.0006 & 0.00025 & $\mathbf{1 8 . 0 6}$ & $\mathbf{3 2}$ & $<3$ \\
\hline Objective & $\mathbf{0 . 0 5}$ & $\mathbf{0 . 0 0 5}$ & $\mathbf{0 . 0 5}$ & $\mathbf{1}$ & $\mathbf{0 . 3}$ & $\mathbf{0 . 1}$ & $\mathbf{0 . 0 5}$ & $\mathbf{0 . 2}$ & $\mathbf{4}$ & $<3$ \\
\hline
\end{tabular}

* The values in bold do not meet the objective. Objective values as per standards given by BDS 2000.

** Except pH, Temperature, Conductivity and Fecal. Coliform other parameters are in mg/L.

The high levels of nitrate and nitrite concentration in drinking water may cause serious illnesses such as methemoglobinemia or "blue baby syndrome" [1,23,25], cancer risks [3,4,38,39,40], increased starchy deposits, and hemorrhaging of the spleen [1]. Nitrate and nitrite concentration in the groundwater samples are investigated to be in a range of 0.00 to $527.81 \mathrm{mg} / \mathrm{L}$ and 0.00 to 24.18 $\mathrm{mg} / \mathrm{L}$, respectively. All investigated data of nitrate during the study period satisfied the objective values for drinking water except GW7 location, high concentration $527.805 \mathrm{mg} / \mathrm{L}$ of nitrate was investigated at this location, due to agricultural activities. Because of this site was more extensive cropping zone. That is too much high concentration from the objective. However, the highest concentration of nitrite was found at the GW9, GW13,GW14,GW15 and GW17 sites respectively
$24.18 \mathrm{mg} / \mathrm{L}, 7.858 \mathrm{mg} / \mathrm{L}, 7.681 \mathrm{mg} / \mathrm{L}, 10.186 \mathrm{mg} / \mathrm{L}$ and $6.75 \mathrm{mg} / \mathrm{L}$, where the BDS guideline for drinking water quality is only $<1.0 \mathrm{mg} / \mathrm{L}$. The almost number of the location nitrite concentration were not met with objective (Table 4).

Chlorides occur in all natural waters in varying concentrations [3]. They are responsible for the salty taste in water $[3,23]$. The investigated values for the chloride concentrations in this study are not met with the suggested objectives of $150-600 \mathrm{mg} / \mathrm{L}$. The investigated values more than lower the BDS. The mean chloride concentration was calculated $17.17 \pm 23.18 \mathrm{mg} / \mathrm{L}$ (Table 4). The lowest chloride concentration was investigated at the GW12, GW13, GW14, GW15, GW16 and GW17 (Table 4), all sites concentration not met to a minimum concentration value of BDS guideline for drinking water quality. 


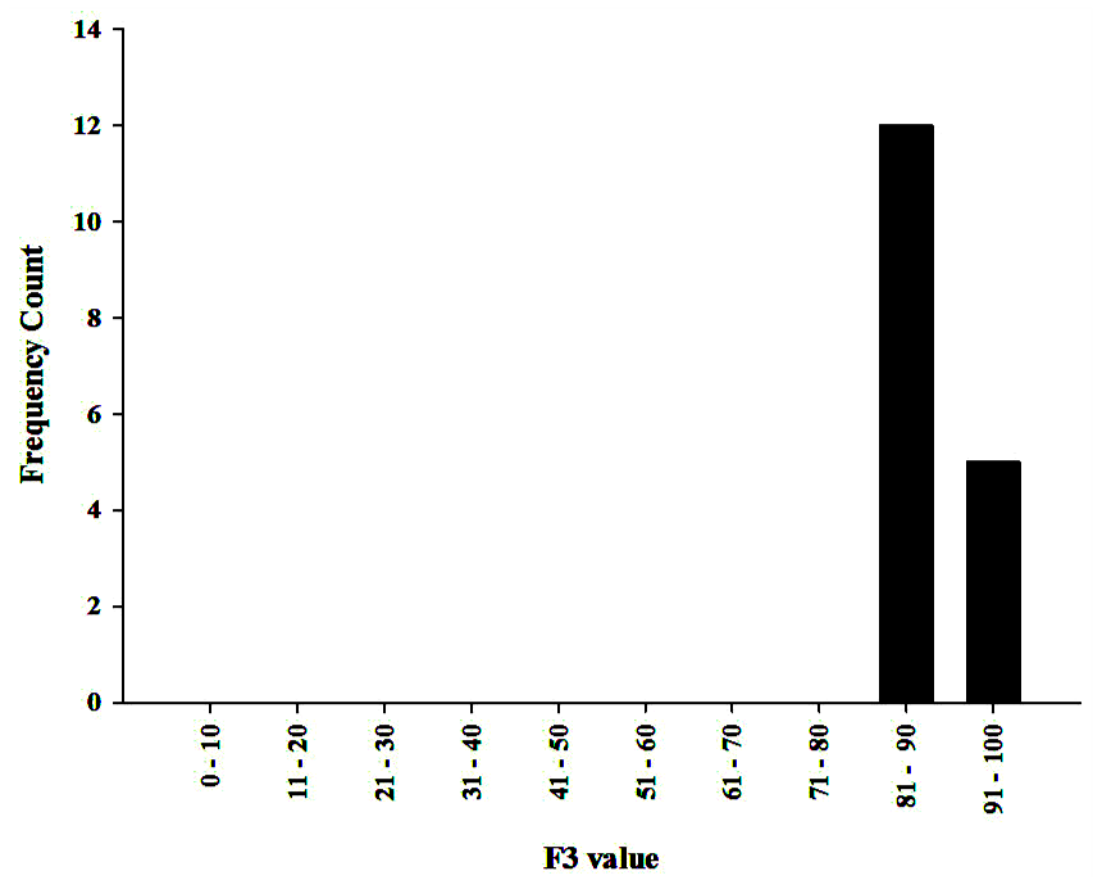

Figure 5. Histogram showing distribution of F3 parameter

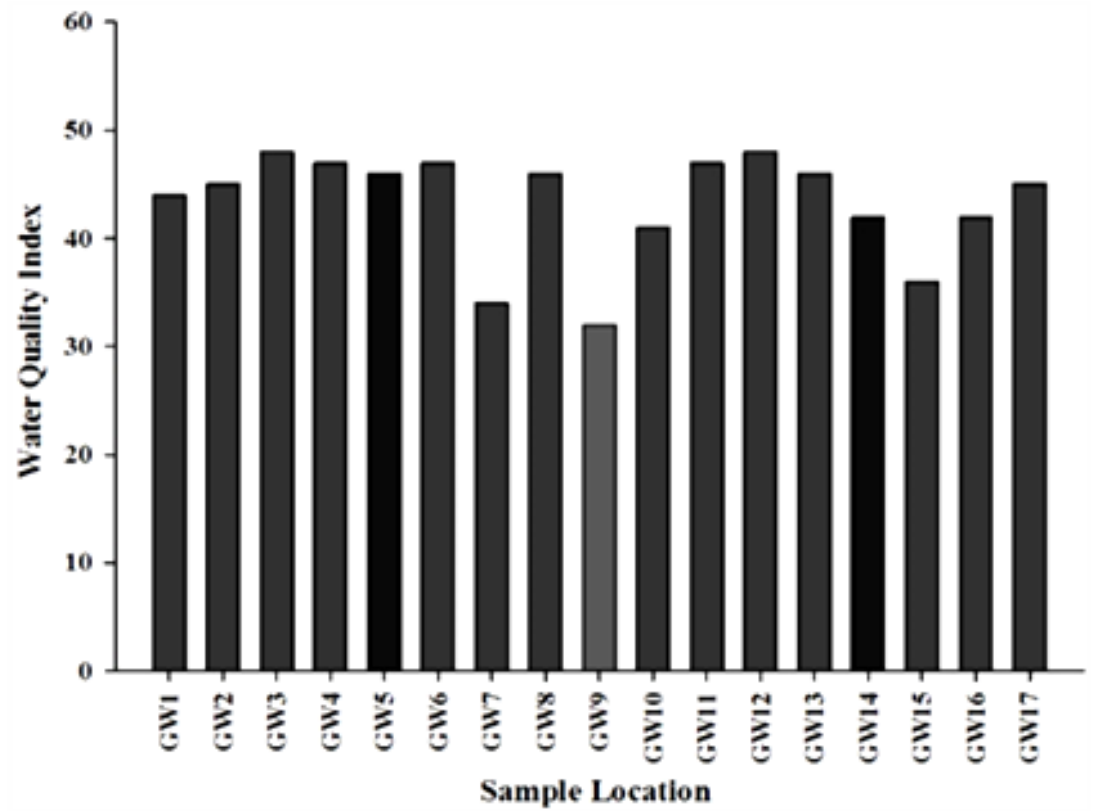

Figure 6. Location wise WQI in ground water at RNPP area

Table 6. Location-wise CCEM-WQI (Drinking categories) of Groundwater quality parameter

\begin{tabular}{|c|c|c|c|c|c|}
\hline $\begin{array}{c}\text { Sample } \\
\text { Location }\end{array}$ & WQI & $\begin{array}{c}\text { WQ } \\
\text { Status }\end{array}$ & $\begin{array}{c}\text { Sample } \\
\text { Locatin }\end{array}$ & WQI & $\begin{array}{c}\text { WQ } \\
\text { Status }\end{array}$ \\
\hline GW1 & 44 & Poor & GW10 & 41 & Poor \\
\hline GW2 & 45 & Marginal & GW11 & 47 & Marginal \\
\hline GW3 & 48 & Marginal & GW12 & 48 & Marginal \\
\hline GW4 & 47 & Marginal & GW13 & 46 & Marginal \\
\hline GW5 & 46 & Marginal & GW14 & 42 & Poor \\
\hline GW6 & 47 & Marginal & GW15 & 36 & Poor \\
\hline GW7 & 34 & Poor & GW16 & 42 & Poor \\
\hline GW8 & 46 & Marginal & GW17 & 45 & Marginal \\
\hline GW9 & 32 & Poor & *Total no of sample 17 \\
\hline
\end{tabular}

All sampling location were found fecal coliform, where the Bangladesh standard for drinking water quality fecal coliform guideline value is zero or nil (Table 4). The average fecal coliform count was $24.74 \pm 59.424 \mathrm{MPN} / 100 \mathrm{~mL}$. Water may be contaminated with microorganisms waste from humans and animals, even the micro-organisms contaminated from the source of soil and surface water. Besides, contamination may also occur during distribution or transportation.

$\mathrm{pH}$, Potassium, Sodium, Sulphate, Manganese, Lead, Cadmium and Chromium parameters of groundwater are not met with objective value (Table 4 and Table 5). These parameters observed value below the BDS guideline value for drinking water quality (Table 4). The arsenic concentration was found very high at the GW1, GW9 and GW16 sites respectively $0.08427 \mathrm{mg} / \mathrm{L}, 0.49835 \mathrm{mg} / \mathrm{L}$ and $0.16545 \mathrm{mg} / \mathrm{L}$ (Table 5) where the objective value is $0.05 \mathrm{mg} / \mathrm{L}$ for 
drinking water (Table 4). The copper concentration was not met with minimum level of concentration recommended by BDS guideline for drinking water quality.

The high concentration of iron in groundwater was observed at GW3, GW7.GW9. GW10 and GW15 respectively $0.3157 \mathrm{mg} / \mathrm{L}, 0.3280 \mathrm{mg} / \mathrm{L}, 0.4967 \mathrm{mg} / \mathrm{L}$, $0.3080 \mathrm{mg} / \mathrm{L}$ and $0.3710 \mathrm{mg} / \mathrm{L}$. wherever, the objective is $0.30 \mathrm{mg} / \mathrm{L}$ recommended by BDS. Moreover, a few parameters does not met with maximum concentration value for drinking WQ guideline. The Temperature, DO, BOD, COD, Conductivity and Alkalinity concentration investigated value higher than the objective value.

According to the total values of parameters examined, Table 4 and Table 5 calculate drinking category water quality CCME WQI. The total numbers of parameters examined are 22, and the total numbers of individual tests are 374. The number of parameters not meeting objectives are 15 (Temperature, pH, DO, BOD,COD, Conductivity, Alkalinity, Magnesium, Chloride, Nitrate, Nitrite, Arsenic, Copper, Iron and fecal coliforms) and the number of tests not meeting objectives are 189. The calculated values and ratings of WQI are presented in Table 4 and Table 5.

The WQI calculated drinking category rating is 37 indicates that groundwater quality for RNPP area is ranked 'poor'. Where components of CCEM-WQI are Scope F1, Frequency F2 and Amplitude F3 were calculated respectively 53, 52 and 91 (Table 7). The "poor" quality can be attributed to the Water quality is almost always threatened or impaired; conditions usually depart from natural or desirable levels.

Table 7. Calculated values of WQI in RNPP area groundwater

\begin{tabular}{|c|c|c|c|}
\hline No. & Term of index & Value & Rating of water quality \\
\hline 1. & Scope; F1 & 53 & \multirow{4}{*}{$\begin{array}{l}\text { Rank: Poor } \\
\text { Water quality is almost always } \\
\text { threatened or impaired; } \\
\text { conditions usually depart from } \\
\text { natural or desirable levels. }\end{array}$} \\
\hline 2. & Frequency; F2 & 52 & \\
\hline 3. & Amplitude; F3 & 91 & \\
\hline 4. & WQI & 37 & \\
\hline
\end{tabular}

\section{Statistical Interpretation of Correlation}

Correlation analysis done (Table 2 and Table 3) between the WQI, Temperature, pH, Dissolve Oxygen, Biological Oxygen Demand, Chemical Oxygen Demand, Conductivity, Alkalinity, Magnesium, Potassium, Sodium, Chloride, Nitrate, Nitrite, Sulphate, Manganese, Arsenic, Copper, Iron, Lead, Cadmium, Chromium and fecal coliforms (FC). Temperature, $\mathrm{pH}$, Dissolve Oxygen, Potassium, Sodium, Sulphate, Chromium and fecal coliforms (FC) parameters positively impacted the WQI, besides all others parameters negatively impacted the WQI (Table 3). The $\mathrm{SO}_{4}{ }^{2-}$ and $\mathrm{Cr}$ is highly positively correlated with WQI. $\mathrm{Mn}, \mathrm{As}, \mathrm{Fe}, \mathrm{Cd}$ and $\mathrm{NO}_{2}{ }^{2-}$ are highly negatively correlated with WQI. The results highlight a strong correlation among all water quality parameters and WQI.

\section{Conclusion}

The CCME WQI model is an effective and more powerful tool to evaluate water quality for any water reservoirs systems. The WQI model used for rating of drinking water quality in the RNPP area indicates that the quality is "poor" (CCMEWQI is 37) for the year 2017. Temperature, DO, conductivity and $\mathrm{pH}$ are the most important parameter that determinates the rating of water quality, exceeding the standards (objective) of drinking water. To modify this parameter and to increase water quality, during the treatment process water should be implemented, even the filtration process. The information provided by CCME-WQI is a convenient and effective tool for evaluating and describing the state of the drinking water quality and can be of excessive assessment for water end users, state authorities and water resources managers, etc.

\section{Acknowledgments}

We sincerely acknowledge the Designated Reference Institute for Chemical Measurements, Bangladesh, for providing lab facilities to the analysis of water quality parameters. The authors are also thankful to $\mathrm{Md}$. Mojahidul Islam, MS student, Department of Geography and Environment, Jagannath University, Dhaka, Bangladesh for his support at field level data collection.

\section{References}

[1] Aydin, A., "The Microbiological and Physico-Chemical Quality of Groundwater in West Thrace”, Turkey. Pol. J. Environ. Stud. 16, (3), 377, 2007.

[2] Abbasi, T. and Abbasi, S.A., "Water quality indices". Elsevier, Amsterdam, The Netherlands. 2012.

[3] American Public Health Association (APHA, 1998), and Water Pollution Control Federation, Standard methods for the examination of water and waste water $20^{\text {th }}$ ed, Washington D., C., 19987.

[4] Bhargava, D., S., "Use of water quality index for river classification and zoning of Ganga River”, Environ. Pollut. Ser. B., England. 6(1), 51-67, 1983.

[5] Bangladesh Bureau of statistics and UNICEF. "Bangladesh National Drinking Water Quality Survey of 2009”. Dhaka: Planning Division, Ministry of Planning. 2009.

[6] CCME, "Canadian environmental quality guidelines for the protection of aquatic life, CCME water quality index”. Technical report. 1.0. 2001.

[7] CCME (Canadian Council of Ministers of the Environment) Canadian water quality guidelines for the protection of aquatic life: CCME Water Quality Index 1.0, User's Manual. In: Canadian environmental quality guidelines, 1999, Canadian Council of Ministers of the Environment, Winnipeg, 2001.

[8] Dunn G., W., "Trends in water quality variables at the Alberta/Saskatchewan Boundary”. Prepared For The Committee On Water Quality. 1995.

[9] EQS (Environmental Quality Standard).Bangladesh Gazette, Registered. Department of Environment, Ministry of Environment and Forest, Government of Bangladesh. 1997.

[10] Horton, R.K., "An index number system for rating water quality”, J. Water Pollu. Cont. Fed., 37(3). 300-305. 1965.

[11] Michalik, A., "The Use of Chemical and Cluster Analysis for Studying Spring Water Quality in Świętokrzyski National Park”. Pol. J. Environ. Stud. 17, (3), 357, 2008.

[12] Lumb, A., Halliwell, D. and Sharma, T., “Application of CCME water quality index to monitor water quality: a case of the Mackenzie river basin, Canada”. Environ. Monit. Assess. 113. 411-429. 2006.

[13] Nass, S., Bayram, A., Nas, E., Bulut, V., N., "Effects of Some Water Quality Parameters on the Dissolved Oxygen Balance of Streams”, Pol. J. Environ. Stud. 17, (4), 531, 2008. 
[14] Said, A., Stevens, D., K., and Sehlke, G., "An innovative index for evaluating water quality in streams". Environ. Assess. 34(3), 406-414, 2004.

[15] Ongley, E., "Modernization of water quality programs in developing countries: issues of relevancy and cost efficiency". Water Qual. Int. 3(4), 37-42, 1998.

[16] Ongley, E.,D., Booty W.G., "Pollution remediation planning in developing countries: Conventional modelling versus knowledge based prediction”. Water Int., 24, 31-38, 1999.

[17] Poonam, T., Tanushree, B., and Sukalyan, C., "Water Quality Indices- Important Toolsfor Water Quality Assessment: A Review". International Journal of Advances in Chemistry. 1(1), 15-29, 2015.

[18] Tyagi, S., Sharma, B., Singh,P., and Dobhal, R., "Water Quality Assessment in Terms of Water Quality Index". American Journal of Water Resources. 1(3), 34-38, 2013.

[19] Bordalo, A., A, Nilsumranchit, W., and Chalermwat, K., "Water quality and uses of the Bangpakong River (Eastern Thailand)". Water Res. 35(15), 3635-3642, 2001.

[20] Kannel, P., R., Lee, S., Lee, Y.,S., Kanel, S.,R., and Khan, S., P., "Application of water quality indices and dissolved oxygen as indicators for riverwater classification and urban impact assessment. Environ Monit Assess”. 132, 93-110, 2007.

[21] Uddin, M., G., Moniruzzaman, Hoque, M., A., A., Hasan, M., A., and Khan, M., "Seasonal Variation of Physicochemical Properties of Water in the Buriganga River, Bangladesh". World Applied Sciences Journal, 34(1), 24-34, 2016.

[22] Damo, R., and Icka, P.,"Evaluation of water quality index for drinking water. Polish Journal of Environmental Studies”. 22(4), 1045-1051, 2013.

[23] Gupta, P., Vishwakarma, M., Rawtanip, M.,. "Assessment of water quality parameters of Kerwa Dam for drinking suitability". International Journal of Theoretical and Applied Sciences. 1(2), 53, 2009.

[24] Nduka, J., K., Orisakwe, O., E., Ezenweke, L., O., "Some physicochemical parameters of potable water supply in Warri. Niger Delta area of Nigeria”. Scientific Research and Essay, 3, (11), 547, 2008.

[25] Michalski, R., Kurzyca, I., "Determination of Nitrogen Species (Nitrate, Nitrite and Ammonia Ions) in Environmental Samples by Ion Chromatography”. Pol. J.Environ. Stud., 15, (1), 5, 2006.

[26] Sutadian, A., D., Muttil, N., Yilmaz, A., G., and Perera, B., J., C., "Development of river water quality indices-a review". Environmental Monitoring and Assessment. 188(58), 2-29, 2016.

[27] Yogendra, K., Puttaiah, E., T., "Determination of Water Quality Index and Suitability of an Urban Water body in Shimoga Town, Karnataka” The 12th World Lake Conference, Sengupta, M., and Dalwani, R., 342-346, 2008.

[28] Sharma, D., Kansal, A., "Water quality analysis of River Yamuna using water quality index in the national capital territory, India (2000-2009)”. Appl Water Sci. 1,147-157, 2011.

[29] Rocchini, R, Swain, L., G., "The British Columbia water quality index. Water Quality Branch, EP Department, B.C”. Ministry of Environment, Land and Park, Victoria, 1995.

[30] Liou, S., M., Lo, S., L., and Wang, S., H., "A generalized water quality index for Taiwan". Environmental Monitoring and Assessment, 96(1-3), 35-52, 2004.

[31] Maiti, S.,K., Handbook of Methods in Environmental Studies Vol 1: Water and Wastewater Analysis”. (2nd ed.). ABD Publishers, Rajsthan , India, 2004, 26-57.

[32] Hossain, F., R., Afrin, M., Y., Mia, M., A., Akbor, and Ahsan, M., A., "Investigation of Chemical Parameters and Major Anions of
Two Selected Aquaculture Ponds at Santosh Region, Tangail, Bangladesh”. J. Environ. Sci. \& Natural Resources, 7(2): 89-92, 2014.

[33] Ahmed, S., S., "Assessment of Groundwater Quality Parameters Using Multivariate Statistics-A Case Study of Majmaah”, KSA. International Journal of Environmental Monitoring and Analysis, 5(2): 32-40, 2017.

[34] Reza, R., Singh, G., “Assessment of Ground Water Quality Status by Using Water Quality Index Method in Orissa, India”. World Applied Sciences Journal. 9, (12), 1392, 2010.

[35] Bharti, N., and Katyal, D., "Water quality indices used for surface water vulnerability assessment", Int. J. Environ. Sci., 2(1). 154-173, 2011.

[36] EPA (Environment Protection Agency), "parameters of water quality Interpretation and Standards". Environmental Protection Agency, Ireland.24-112, 2001.

[37] Guidelines for Drinking-water Quality, Fourth Edition, World Health Organization, 2012.

[38] Kumari, B., L., Sudhakar, P., Hanuma S., M., Satya, S., K., P., N., V., Analysis of Physico-chemical parameters of water quality in and around Saltpans of Prakasam (Dt.) A.P, Journal of Ecobiotechnology. 3, (10), 01, 2011.

[39] WHO. "Guidelines for Drinking-water Quality". 4th ed.. World Health Organization. Geneva. 396-407, 2011.

[40] Purves, D., "Trace-Element Contaminants. In Massachusetts, S (Ed), Fundamental Aspects of Pollution Control and Environmental Science”. Elsevier Science Publishing Company, Inc. New York, 7-150, 1985

[41] Wikipediaorg. 2017. Wikipediaorg. [Online]. [18 April 2017]. Available from: https://en.wikipedia.org/wiki/Ishwardi_Upazila

[42] Terrado, M., Barceló, D., Tauler, R., Borrell, E., Campos, S. D., and Barceló, D., (2010). Surface-water-quality indices for the analysis of data generated by automated sampling networks. TrAC, Trends in Analytical Chemistry, 29(1), 40-52, 2010.

[43] Mostafaei, A., "Application of multivariate statistical methods and water quality index to evaluation of water quality in the Kashkan River”. Environmental Management, 53(4), 865-881, 2014.

[44] Khan, A., A., Paterson, R., and Khan, H., "Modification and application of the Canadian Council of Ministers of the Environment Water Quality Index (CCME WQI) for the communication of drinking water quality in Newfoundland and Labrador”. Water Quality Research Journal of Canada, 39(3), 285-293, 2004.

[45] Smith, D. G., "A better water quality indexing system for rivers and streams". Water Research, 24(10), 1237-1244, 1990.

[46] Siasar,H., Tolouei, B., "Ground water quality assessment of Iranshahr for use in urban areas", Journal of Biodiversity and Environmental Sciences .6 (3), 530-534, 2015.

[47] Chapman, D. (UNESCO, WHO, and UNEP). Water quality assessment. London: Chapman \& Hall. 1992.

[48] Venkatramanan, S., Chunga, S., Y., Ramkumar, T., Rajesh, R., Gnanachandrasamy, G., "Assessment of groundwater quality using GIS and CCME WQI techniques: a case study of Thiruthuraipoondi city in Cauvery deltaic region, Tamil Nadu, India”. Desalination and Water Treatment, 57, 12058-12073, 2016.

[49] Hossein Banejad, H., Olyaie, E., "Application of an Artificial Neural Network Model to Rivers Water Quality Indexes Prediction - A Case Study" Journal of American Science. 7(1), 60-65, 2011.

[50] Phadatare, S., S., Gawande, S., "Review Paper on Development of Water Quality Index". International Journal of Engineering Research \& Technology. 5(5), 765-767, 2016. 